\title{
THE THERMAL BEHAVIOR OF THE BINARY SYSTEMS OF LITHIUM-POTASSIUM PHOSPHATES
}

\author{
TETSUYA YAMASHITA,HIROYUKI NARIAI, and ITARU MOTOOKA \\ Department of Chemical Science and Engineering, Faculty of Engineering, \\ Kobe University, Rokkodai-cho, Nada-ku, Kobe 657
}

\begin{abstract}
The thermal behavior of some phosphates, lithium hydrogen phosphates represented by LixH3-xPO4 $(x=1,1.5,2)$ mixed with potassium dihydrogen phosphate, were investigated using DTA-TG, XRD and HPLC-FIA. These results showed a formation region, and the reason for the formation of cyclic phosphates was discussed.

The formation region in $\mathrm{LiH} 2 \mathrm{PO} 4-\mathrm{KH} 2 \mathrm{PO} 4$ system, $\mathrm{LiH} 2 \mathrm{PO} 4$ and $\mathrm{KH} 2 \mathrm{PO} 4$ influenced. The samples of $\mathrm{R}$ (indicated that the molar ratio of $\mathrm{LiH} 2 \mathrm{PO} 4$ to $\mathrm{KH} 2 \mathrm{PO} 4) \fallingdotseq 1: 1$ therefore showed original thermal behaviors in which cyclic phosphates were produced slightly above $450^{\circ} \mathrm{C}$. In the $\mathrm{Li1} 1.5 \mathrm{H} 1.5 \mathrm{PO} 4-\mathrm{KH} 2 \mathrm{PO} 4$ system, the addition of $\mathrm{KH} 2 \mathrm{PO} 4$ to Li1.5H1.5PO4 greatly influenced the thermal behavior of Li1.5H1.5PO4 and suppressed the change of $\mathrm{Li} 1.5 \mathrm{H} 1.5 \mathrm{PO} 4$ to $\mathrm{Li} 3 \mathrm{HP} 2 \mathrm{O} 7$, while the addition of Li1.5H1.5PO4 to KH2PO4 influenced slightly the thermal behavior of $\mathrm{KH} 2 \mathrm{PO} 4$. In the $\mathrm{Li} 2 \mathrm{HPO} 4-\mathrm{KH} 2 \mathrm{PO} 4$ system, the addition of $\mathrm{KH} 2 \mathrm{PO} 4$ to Li2HPO4 influenced slightly the thermal behavior of $\mathrm{Li} 2 \mathrm{HPO} 4$, while the addition of $\mathrm{Li} 2 \mathrm{HPO} 4$ to $\mathrm{KH} 2 \mathrm{PO} 4$ influenced that of $\mathrm{KH} 2 \mathrm{PO} 4$.

Although the thermal behavior of Li1.5 $1.5 \mathrm{PO} 4$ due to heating was the disproportionation reaction which was composed of the main-reaction ( the formation of linear poly-phosphate) and a side-reaction (that of cyclicphosphate), the addition of $\mathrm{KH} 2 \mathrm{PO} 4$ to $\mathrm{Li} 1.5 \mathrm{H} 1.5 \mathrm{PO} 4$ restricted the sidereaction to some extent. This seems to be due to the suppression of the formation of Li3HP2O7 producted at first step of the side-reaction.
\end{abstract}

\section{INTRODUCTION}

It is well-known that the hydrogen ortho-phosphates changes easily to linear or cyclic condensed phosphates by heating. The linear or cyclic structure is influenced by the kind of the cation, the cation-phosphorus ratio, heating temperature, etc. For example, on heating, $\mathrm{NaH} 2 \mathrm{PO} 4$ and $\mathrm{LiH}_{2} \mathrm{PO} 4$

Received October 18, 1995; Accepted December 4, 1995 
changes to cyclic and/or linear condensed phosphates, and $\mathrm{KH} 2 \mathrm{PO} 4$ changes to linear ones. The complex behavior of lithium salt is caused by the disproportionation shown in the Scheme. The main-reaction produced only linear condensed phosphates and the side-reaction produced cyclic condensed phosphates. It is interesting to investigate the thermal behavior of the binary system of alkali metal phosphates which have such different properties.

In this work, we mainly studied the lithium phosphate which showed a unique reaction on the process of thermal change and we investigated the thermal behavior of the binary system of lithium and potassium phosphates using DTA-TG, XRD and HPLC-FIA.

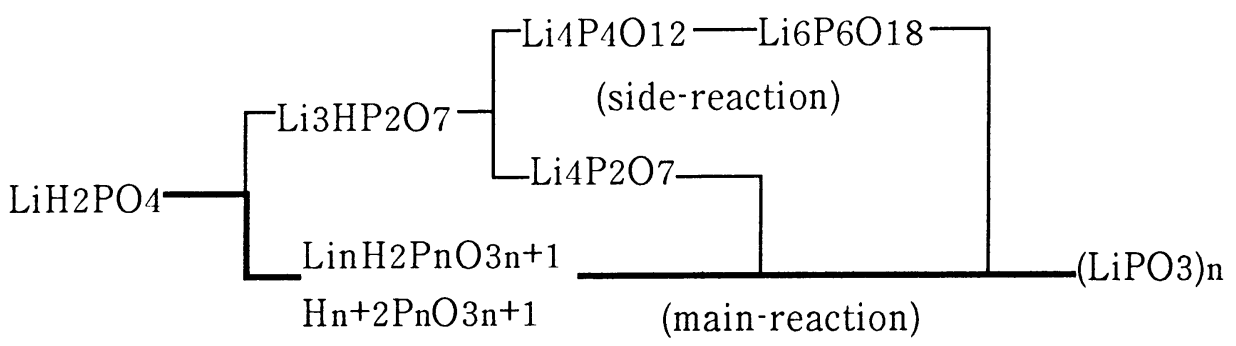

SCHEME Thermal Dehydration of $\mathrm{LiH}_{2} \mathrm{PO} 4{ }^{2}$ )

\section{EXPERIMENTAL}

\section{Preparation of samples for heating}

The lithium phosphates(LixH3-xPO4) were prepared by mixing $\mathrm{Li} 2 \mathrm{CO} 3$ and $\mathrm{H} 3 \mathrm{PO} 4(85 \%)$ and then heating the mixture at $50^{\circ} \mathrm{C}$. The phosphates obtained were analysed using HPLC-FIA, XRD, DTA-TG and ICP. From analytical results, lithium phosphates represented by $\mathrm{Li1} 1.5 \mathrm{H} 1.5 \mathrm{PO} 4$ and $\mathrm{Li} 2 \mathrm{HPO} 4$ were composed of $3 \mathrm{LiH} 2 \mathrm{PO} 4+\mathrm{Li} 3 \mathrm{PO} 4$ and $\mathrm{LiH} 2 \mathrm{PO} 4+\mathrm{Li} 3 \mathrm{PO} 4$, respectively. The samples for heating were prepared by mixing LixH3-xPO4 with $\mathrm{KH} 2 \mathrm{PO} 4$ at several molar ratios $\mathrm{R}(\mathrm{LixH} 3 \cdot \mathrm{xPO} 4 / \mathrm{KH} 2 \mathrm{PO} 4)=10 / 1 \sim 1 / 10$.

\section{Heating and Analysis}

DTA-TG equipment was used to investigate the thermal behavior. The mixed samples were heated around the temperature shown by the DTA peaks; the heated products were cooled immediately and analysed using HPLC-FIA and XRD. 
RESULTS AND DISCUSSION

\section{$\mathrm{LiH}_{2} \mathrm{PO}_{4}-\mathrm{KH}_{2} \mathrm{PO}_{4}$ system}

Figure 1 shows the DTA-TG curves of the sample of $\mathrm{R}$ ( $\mathrm{LiH} 2 \mathrm{PO} 4$ $/ \mathrm{KH} 2 \mathrm{PO} 4)=10 / 1$. The large endothermic peaks around $220^{\circ} \mathrm{C}$, some exothermic peaks around $320^{\circ} \mathrm{C}$, small peaks around $390^{\circ} \mathrm{C}$ and an endothermic peak around $610^{\circ} \mathrm{C}$ were observed. The products heated at each temperature shown by arrows in Fig. 1 were analysed. Table 1 and Fig. 2 show the results

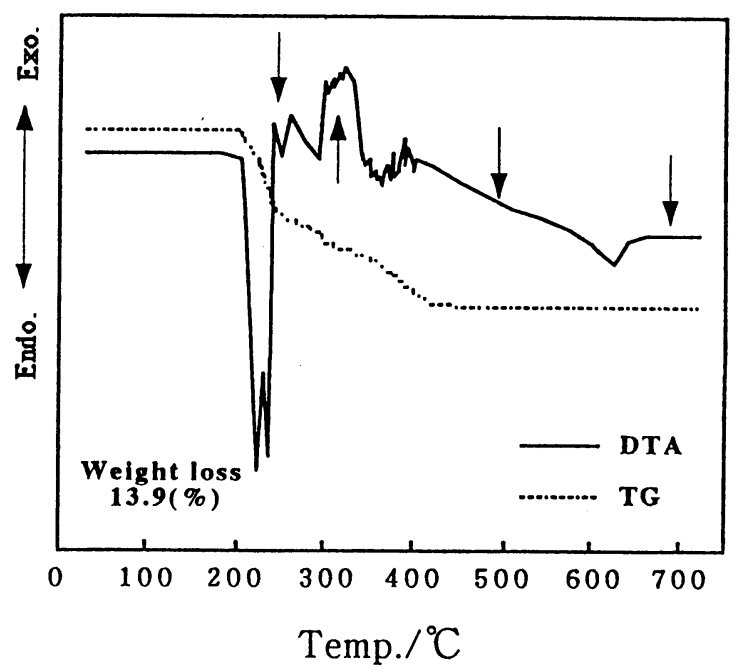

FIGURE 1 DTA-TG Curves of $\mathrm{R}(\mathrm{LiH} 2 \mathrm{PO} 4 / \mathrm{KH} 2 \mathrm{PO} 4)=10 / 1$ Sample.

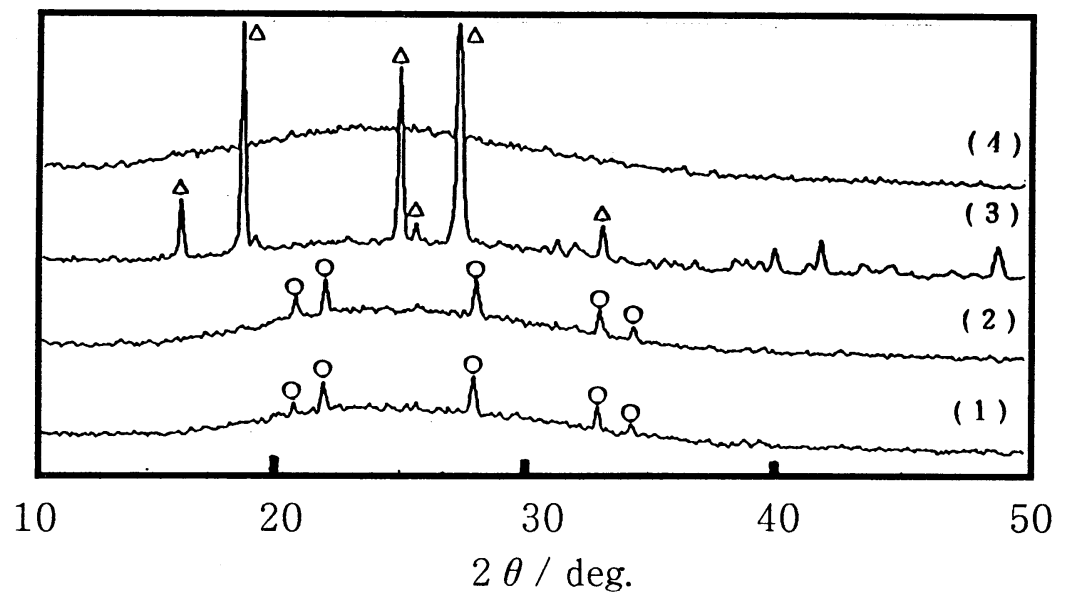

FIGURE 2 X-Ray Diffraction Patterns of Products Heated at Several Temperatures in $\mathrm{LiH} 2 \mathrm{PO} 4 / \mathrm{KH} 2 \mathrm{PO} 4=10 / 1$ (R) System.

$\mathrm{O}$; Li3HP2O7 $\triangle$; (LiPO3)n ; (1) $225^{\circ} \mathrm{C}$ (2) $320^{\circ} \mathrm{C}$ (3) $490^{\circ} \mathrm{C}$ (4) $700^{\circ} \mathrm{C}$

of HPLC-FIA and XRD, respectively. From Table 1 , the two peaks at $220^{\circ} \mathrm{C}$ are the condensation reaction from ortho- to pyro-phosphate, and the change from 220 to $390^{\circ} \mathrm{C}$ is the condensation from low-polymer to high-polymer.

The peak at $660^{\circ} \mathrm{C}$ was due to melting of poly-phosphate. The X-ray diffraction patterns (Fig.2) of products at 225 and $320^{\circ} \mathrm{C}$ showed those of Li3HP2O7 which had low-crystallinity. Those at $490^{\circ} \mathrm{C}$ and $700^{\circ} \mathrm{C}$ showed 
TABLE 1 Changes in the Amounts of Phosphate Compounds of the Samples Heated at Several Temperatures in $\mathrm{LiH} 2 \mathrm{PO} 4 / \mathrm{KH} 2 \mathrm{PO} 4=10 / 1(\mathrm{R})$ System

\begin{tabular}{lrrrrcrrrr}
\hline Compound a) & P1 & P2 & P3 & Polig. & P6m & P4m & P3m & Ppoly. & Pinsol. \\
\hline $225\left({ }^{\circ} \mathrm{C}\right)$ & 17.1 & 45.1 & 5.5 & 6.5 & 0.0 & 0.0 & 0.0 & 0.0 & 25.8 \\
$320\left({ }^{\circ} \mathrm{C}\right)$ & 6.7 & 27.4 & 10.5 & 26.2 & 0.0 & 0.0 & 0.0 & 0.0 & 29.2 \\
$490\left({ }^{\circ} \mathrm{C}\right)$ & 0.0 & 0.0 & 0.5 & 2.6 & 0.0 & 0.0 & 0.0 & 3.3 & 93.6 \\
$700\left({ }^{\circ} \mathrm{C}\right)$ & 0.0 & 0.0 & 0.0 & 0.0 & 0.0 & 0.0 & 0.0 & 11.8 & 88.2 \\
\hline
\end{tabular}

a) P1, P2, P3, Polig., P6m, P4m, P3m, Ppoly. and Pinsol. represent ortho-, pyro-, tri-, olig.-(chain length, $\mathrm{n}=5-9$ ), cyclo-hexa-, cyclo-tetra-, cyclo-tri-, poly.(chain length, $\mathrm{n}=9-20$ ) and insoluble phosphate, respectively.

lithium poly-phosphate and amorphous phase, respectively. These results of $\mathrm{XRD}$ supported those of HPLC-FIA.

The same experiments were carried out for several samples with different molar ratios and the diagrams of the formation region were designed.

Figure 3 shows the formation region in the $\mathrm{LiH} 2 \mathrm{PO} 4-\mathrm{KH} 2 \mathrm{PO} 4$ system. In this figure, the abbreviation (amo.) indicates an amorphous phase, as seen from $X R D$ results.

In the region of $1 / 2<R<2$, cyclicphosphates, i.e., cyclotri-(P3m) in the yield of $1 \%$, cyclotetra-(P4m) in $1 \%$ and cyclohexa(P6m) phosphate in $1 \%$, were produced at higher temperature, except for the absence of

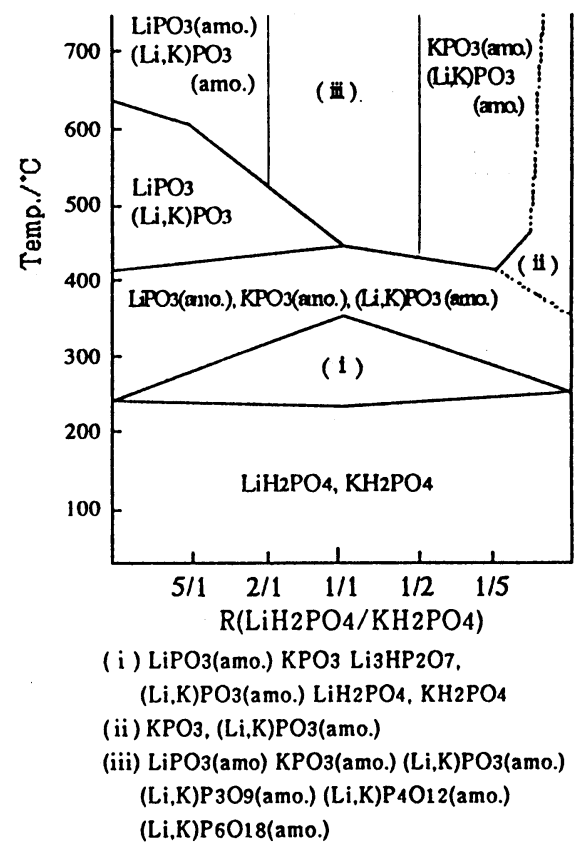

FIGURE 3 Formation Region in $\mathrm{LiH} 2 \mathrm{PO} 4-\mathrm{KH} 2 \mathrm{PO} 4$ System. $\mathrm{P} 4 \mathrm{~m}$ and $\mathrm{P} 6 \mathrm{~m}$ above $600^{\circ} \mathrm{C}$. These cyclicphosphates in this region do not produce through the side-reaction of the disproportionation reaction, but produce by the convenient cleavage of the P-O-P linkages of spiral structure of high polymer.

\section{Li1.5H1.5PO4-KH2PO4 system}

Figure 4 shows the fomation region in the $\mathrm{Li} 1.5 \mathrm{H} 1.5 \mathrm{PO} 4-\mathrm{KH} 2 \mathrm{PO} 4$ system. A little addition of $\mathrm{KH} 2 \mathrm{PO} 4$ to $\mathrm{Li1} 1.5 \mathrm{H} 1.5 \mathrm{PO} 4$ influenced the thermal behavior 


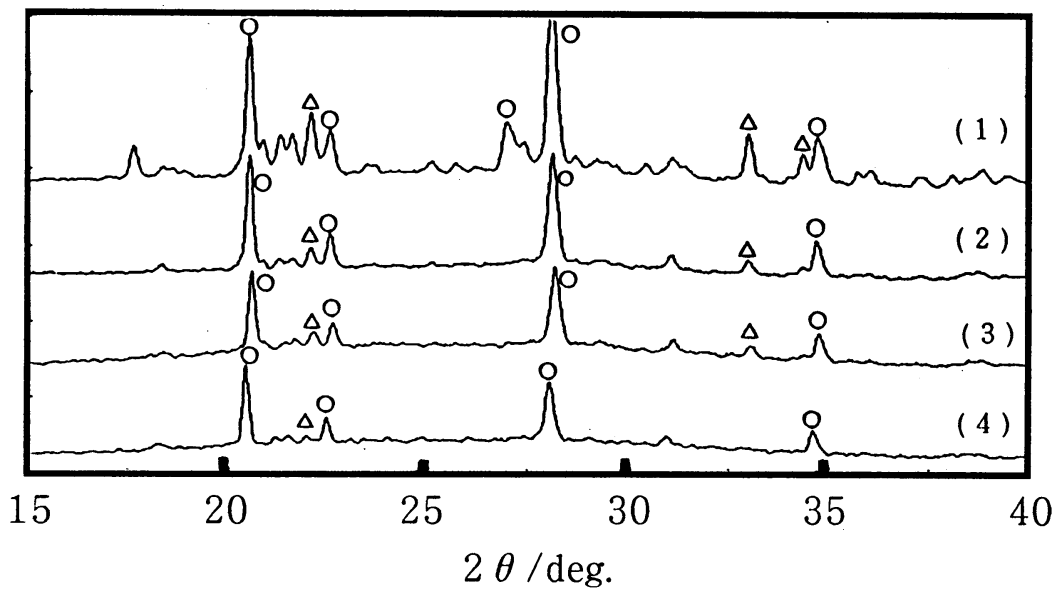

FIGURE 5 X-Ray Diffraction Patterns of Products Heated at Relative Low Temperature. $\bigcirc$; Li3HP2O7 $\triangle$; Li4P2O7(III)
(1) Li1.5H1.5PO4, $315^{\circ} \mathrm{C}$
(2) $\mathrm{R}=20 / 1,288^{\circ} \mathrm{C}$
(3) $\mathrm{R}=10 / 1,285^{\circ} \mathrm{C}$
(4) $\mathrm{R}=5 / 1,315^{\circ} \mathrm{C}$

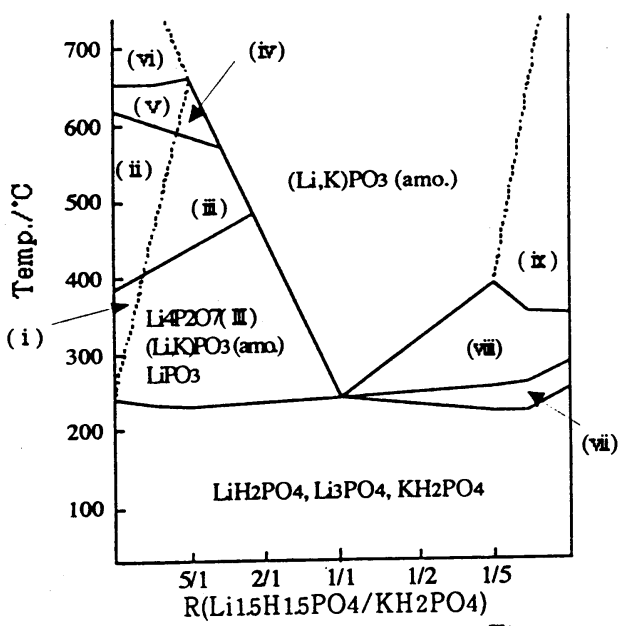

(i) $\mathrm{Li} 4 \mathrm{P} 4 \mathrm{O} 12$. $\mathrm{Li} 3 \mathrm{HP} 2 \mathrm{O} 7, \mathrm{Li} 4 \mathrm{P} 2 \mathrm{O}$ (III). (Li,K)PO3(amo.), $\mathrm{LiPO}$

(ii) $\mathrm{Li}_{4} \mathrm{P} 4 \mathrm{O} 12, \mathrm{Li} 4 \mathrm{P} 2 \mathrm{O} 7$ (II), (Li,K)PO3(amo.), $\mathrm{LiPO} 3$

(iii) $\mathrm{Li}_{4} \mathrm{P} 2 \mathrm{O}$ 7 (II), (Li,K)PO3(amo.). $\mathrm{LiPO} 3$

(iv) $\mathrm{Li}_{4} 4 \mathrm{P} 2 \mathrm{O} 7$ ( II). ( $\left.\mathrm{Li}, \mathrm{K}\right) \mathrm{PO} 3$ (amo.), $\mathrm{LiPO}_{3}$

(v) $\mathrm{Li} 4 \mathrm{P} 4 \mathrm{O} 12$, Li6P6O18. Li4 P2O7(II), (Li,K)PO3(amo.), $\mathrm{LiPO}$

(vi) $\mathrm{Li} 6 \mathrm{P} 6 \mathrm{O}_{18}$ (amo.), $\mathrm{Li} 4 \mathrm{P} 2 \mathrm{O} 7$ (II). ( $\mathrm{Li}, \mathrm{K}) \mathrm{PO} 3$ (amo.), $\mathrm{LiPO} 3(\mathrm{amo}$.

(vii) $\mathrm{KH} 2 \mathrm{PO} 4, \mathrm{KPO} 3(\mathrm{amo}$.$) , ( \mathrm{Li}, \mathrm{K}) \mathrm{PO} 3$ (amo.)

(vii) $\mathrm{KPO}$ (amo.), (Li,K)PO3(amo.)

(ix) KPO3, (Li,K)PO3(amo.)

FIGURE 4 Formation Region in

Li1.5H1.5PO4-KH2PO4 System.

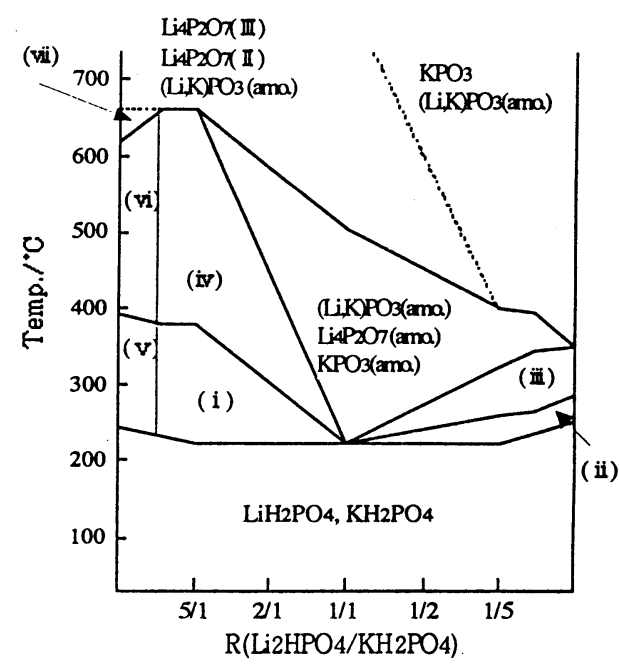

(i) $\mathrm{Li} 4 \mathrm{P} 2 \mathrm{O} 7$ (II), $\mathrm{Li} 3 \mathrm{HP} 2 \mathrm{O} 7, \mathrm{Li}_{3} \mathrm{PO}_{4}$,(Li,K)PO3(amo.)

(ii) $\mathrm{KH} 2 \mathrm{PO} 4$, (Li,K)PO3(amo.)

(iii) $\mathrm{KPO}$ (amo.), ( $\mathrm{Li}, \mathrm{K}) \mathrm{PO}$ (amo.)

(iv) $\mathrm{Li}_{4} \mathrm{P} 2 \mathrm{O} 7$ (II), ( $\left.\mathrm{Li}, \mathrm{K}\right) \mathrm{PO} 3$ (amo.)

(v) $\mathrm{Li}_{3} \mathrm{PO} 4, \mathrm{Li} 4 \mathrm{P} 2 \mathrm{O} 7$ (II), $\mathrm{Li} 3 \mathrm{HP} 2 \mathrm{O} 7, \mathrm{Li} 4 \mathrm{P}_{4} \mathrm{O} 12$

(vi) $\mathrm{Li3PO} 4, \mathrm{Li} 4 \mathrm{P} 2 \mathrm{O}$ ( III), Li6P6O18

(vii) $\mathrm{Li} 4 \mathrm{P} 2 \mathrm{O} 7$ (III), $\mathrm{Li} 4 \mathrm{P} 2 \mathrm{O} 7$ (II), $\mathrm{Li}_{3} \mathrm{PO}_{4}$

FIGURE 6 Formation Region in Li2HPO4-KH2PO4 System. 
of Li1.5H1.5PO4. P4 4 in the yield of about $20 \%$ and $\mathrm{P} 6 \mathrm{~m}$ in about $35 \%$ were produced when Li1.5H1.5PO4 alone was heated at 500 and $700^{\circ} \mathrm{C}$, respectively. However, cyclic-phosphates ( $\mathrm{P} 4 \mathrm{~m}$ and $\mathrm{P} 6 \mathrm{~m})$ in $9 \%$ were produced by heating of the sample of $R=10 / 1$, and no cyclic-phosphates was produced from the samples of $R \leqq 5 / 1$ at any temperature. Figure 5 shows $X$-ray diffraction patterns of products heated at relatively low temperature. The heated product of $\mathrm{Li1} .5 \mathrm{H} 1.5 \mathrm{PO} 4$ had the strong peaks of $\mathrm{Li} 3 \mathrm{HP} 2 \mathrm{O} 7$. As $\mathrm{R}$ value decreased, the intensity of the peaks of $\mathrm{Li} 3 \mathrm{HP} 2 \mathrm{O} 7$ became weaker. This indicates that the addition of $\mathrm{KH} 2 \mathrm{PO} 4$ suppressed the change of $\mathrm{Li1} .5 \mathrm{H} 1.5 \mathrm{PO} 4$ to Li3HP2O7.

Thus, in the region of $\mathrm{R}>5$, the disproportionation reaction occured, though it was affected to some extent by the addition of $\mathrm{KH} 2 \mathrm{PO} 4$. On the other hand, in the region of $\mathrm{R} \leqq 5$, the addition of Li1.5H1.5PO4 to $\mathrm{KH} 2 \mathrm{PO} 4$ influenced slightly the thermal behavior of $\mathrm{KH} 2 \mathrm{PO} 4$.

\section{Li2HPO4-KH2PO4 system}

Figure 6 shows the formation region in the Li2HPO4-KH2PO4 system. The addition of $\mathrm{KH} 2 \mathrm{PO} 4$ to Li2HPO4 did not greatly influence the thermal behavior of $\mathrm{Li}_{2} \mathrm{HPO} 4$ because $\mathrm{Li} 4 \mathrm{P} 2 \mathrm{O} 7$ (III) is stable. However, cyclicphosphate was suppressed to product, e.g., $1 \%$ of $\mathrm{P} 4 \mathrm{~m}$ was produced at $400^{\circ} \mathrm{C}$. At the sample of $R=10 / 1$, however, no cyclic-phosphate was produced at any temperature.

The addition of $\mathrm{Li} 2 \mathrm{HPO} 4$ to $\mathrm{KH} 2 \mathrm{PO} 4$ influenced the thermal behavior of $\mathrm{KH} 2 \mathrm{PO} 4$. The product of $\mathrm{R}=1 / 2$ sample heated at about $500^{\circ} \mathrm{C}$ showed the $\mathrm{X}$-ray diffraction patterns of $\mathrm{Li} 4 \mathrm{P} 2 \mathrm{O} 7(\mathrm{II})$ and $\mathrm{Li} 4 \mathrm{P} 2 \mathrm{O} 7(\mathrm{II})$. One reason for these results may be that many lithium cations are present in this region, and thus the molar ratio of cation to phosphorus was high.

\section{REFERENCE}

1) J.R.Van Wazer, Phosphorus and Its Compounds, Vol. I and II, Interscience Publishers Inc, New York (1961).

2) U.Schulke, Z. Anorg. Allg. Chem., 531, 167 (1985).

3) H.Nariai, I.Motooka, Y.Kanaji, and M.Tsuhako, Bull. Chem. Soc. Jpn., $\underline{60}$, 1337(1987).

4) H.Nariai, I. Motooka, and M. Tsuhako, Phosphorus Research Bulletin, $\underline{2}$, 45(1992). 